\title{
Interview with Margret Meagher
}

Executive Director, Arts and Health Australia (AHA)

ROSS W. PRIOR, University of Wolverhampton

Margret Meagher is the founding executive director of Arts and Health Australia, a national networking and advocacy organization, dedicated to the promotion of best practice arts and health policy, programmes, health education and research. Margret is also a founding board member of The Australian Centre for Arts and Health Limited (ACAH), a not-for-profit organization, established as the peak body for the arts and health sector nationally and representing Australia within the international arts and health field. ACAH is the convenor of the annual 'Art of Good Health and Wellbeing' international arts, health and creative ageing conference, which celebrated its $10^{\text {th }}$ anniversary in November 2018.

Margret is a member of the New South Wales (NSW) Ministerial Advisory Council on Ageing (2011 to present) where she has been pivotal in the development of a creative ageing strategy for the NSW Government. Following her role in the development of the NSW Health and the Arts Framework (2015-2016), Margret was appointed to NSW Health Infrastructure's Arts Advisory Panel in 2018, to support arts and health design and programmes for public health services.

\section{$<$ Insert Figure 1 around here $>$}

Figure 1: Margret Meagher (CMargret Meagher).

Ross Prior: Your career spans 50 years in the arts, marketing communications and event management. You have managed art galleries, published arts, health and tourism magazines, curated art collections and worked as a creative director in advertising agencies across television, radio and print media. How has this background brought you to work in arts and health?

Margret Meagher: In the 90s, I was appointed to the board of the Royal Australian College of General Practitioners' Research Foundation to contribute to its marketing communications strategy. I brought to this role, my burgeoning interest in arts and health. Having identified the high level of interest in the arts by Australian health professionals, I decided to create a 
publication for doctors entitled Arts + Medicine. Through a partnership with a national medical magazine, we mailed 50,000 copies of each issue to GPs and specialists.

The purpose of the magazine was to promote the use of different arts programmes for chronic conditions such as mental health, cardiovascular and respiratory disease, obesity, diabetes, arthritis, substance abuse. The magazine profiled doctors who effectively utilised creative engagement in their holistic treatment of patients.

RP: In 2009 you founded a leading annual conference in Australia focussing on arts, health and creative ageing. Coincidentally that was the first year that the Journal of Applied Arts and Health was published. What led you to convene this conference?

MM: As I became more interested in the concept of arts and health and establishing a peak body for Australia, I developed relationships with international leaders in this field, particularly in the UK and the US. I attended my first international arts and health conference in 2005 in Edmonton, Canada, organised by the Society for Arts in Healthcare (SAH) and thereafter committed to attending SAH's conference each year. In 2011, I became the only Australian to be named a Distinguished Fellow.

SAH conferences demonstrated to me the potential for creating a similar conference in Australia, bringing international leaders to share their knowledge and experience with Australian practitioners and researchers. The conference took shape over 4 years, with support from the Federal Health Department and stakeholders such as the National Gallery of Australia, Canberra and Regional Arts NSW. UK and US friends and colleagues generously shared the outcomes of their work and encouraged me in this endeavour.

Our first conference was held in the regional town of Port Macquarie, on the Mid North Coast of NSW in 2009. International speakers from the UK included Mike White (Medical Humanities, Durham University), Alison Clough (Looking Well, Bentham), Alice Thwaite (Equal Arts), Clive Parkinson (Manchester Metropolitan University). Speakers from the US included Paula Terry (National Endowment for the Arts), Susan Perlstein (National Center for Creative Aging and Elders Share the Arts), Naj Wikof (SAH), Carrie McGee (Museum of Modern Art, New York). This conference attracted over 330 delegates and reaffirmed the opportunity to move the conference around the country to spread the arts and health message on a national basis.

Subsequently, conferences were held at the National Gallery of Victoria, Melbourne (2010), National Gallery of Australia, Canberra (2011), Notre Dame University, Fremantle 
(2012), College of Fine Arts, University of NSW and Art Gallery of NSW, Sydney (2013), National Gallery of Victoria, Melbourne (2014), Sydney Opera House and Art Gallery of NSW (2015), Art Gallery of NSW (2016 \& 2017) and Port Macquarie for its 10th anniversary (2018).

$\boldsymbol{R P}:$ What have been the major issues stemming from your annual conferences and have you seen a change in the agenda across those ten years?

MM:Over the past decade, we have witnessed a number of changes in the arts and health field, including the strong development of the special interest area of creative ageing. In the US, this was led by co-founders of the creative ageing field, Dr Gene Cohen and Susan Perlstein and in the UK, the Baring Foundation became the pivotal funder of creative ageing programmes and events in the UK and internationally.

For three years $(2015,2016,2017)$, the Baring Foundation funded two UK presenters to attend our conference which had a strong impact on our ability to review and adapt ideas around creative ageing festivals, music programmes, public access and education programmes in museums and galleries.

The international arts and health field has expanded greatly and our conference has played a role in fostering international partnerships which now encompass Canada, Singapore, Hong Kong, Japan, Malaysia, Saudi Arabia, Norway, Sweden, Finland, Holland, France, Germany, South Africa and New Zealand. The rise of digital communications has facilitated this international network.

RP: Margret, you strongly believe in the need for interconnection between generations, with old and young taking part in a 'knowledge transfer'. You advocate for older people teaching the young knitting or other crafts, and the young, in turn, teaching their elders how to use technology. Can you elaborate on what makes this so important?

MM: Intergenerational arts and health programmes are vital if we are to continue to develop the field across cultures and maintain healthy growth and sustainability. Engaging with younger members of society is also critical for behavioural change in areas such as ageism and stigma associated with mental health and physical disability. At the core of intergenerational programming is the sharing of knowledge, personal stories, creative ideas which is mutually beneficial to young and older people alike. This interchange leads to 
mutual respect and an understanding of the value that each generation can bring to the other, the sense of achievement and mastery that comes from shared projects and the fostering of self-esteem, self-confidence and social interaction skills. With considerable changes to family infrastructure in our society over recent years, intergenerational arts programmes nurture ways to form caring and enduring friendships and personal relationships.

$\boldsymbol{R P}:$ This leads me to ask about your work with the New South Wales Government Ministerial Advisory Council (formerly 'Committee') on Ageing. You advocate altering people's approach to the elderly so they are not doing things 'for' but 'with' older people. Would you say more about this and the role local government has to play in the way older people live their lives?

MM: In 2011, I was invited to join the Council because of my work in creative ageing. This had developed through meeting Dr Gene Cohen, American psychiatrist and gerontologist, at an arts and health conference in 2006, where he opened his keynote with the words 'Art is like chocolate for the brain'. I was hooked! Gene Cohen became a mentor to me until his untimely death in 2009. I greatly valued his interest and friendship, along with his colleague Susan Perlstein, affectionately known as the 'Grandmother of Creative Ageing'. They emphasised to me the importance of seeing older people as an asset and not a burden on society - recognising and valuing what older people bring to the community in terms of experience, wisdom, knowledge and compassion is integral to ageing well in society.

It is logical that people will respond more positively to creating and participating in activities and being involved in decision making rather than have things done for them. For older people this can take them from feeling they are invisible to a place of acknowledgment and recognition of what they bring to their community. The rapidly ageing population worldwide brings with it immense challenges in providing adequate health and ageing services.

Local government has a crucial role to play in addressing the social needs of its older people and making access freely available to creative activities and experiences in their region. This relies on transport options, scheduling of daytime exhibitions and performances in arts centres, community meeting places, libraries and schools, a well-prepared and implemented policy in relation to Access and Disability and fostering Dementia Friendly communities. Too often local authorities focus on 'roads, rates and rubbish' rather than 
devising cost efficient arts programmes which enhance the health and wellbeing of their community members.

Keeping older people socially involved in community life is essential to reduce reliance on healthcare treatment and hospitalisation. It is about prevention and keeping people safe and ageing well at home. I would like to see stronger business cases for arts and health that convince local government to allocate resources for creative services and activities that support older people to build resilience and maintain good mental and physical health.

$\boldsymbol{R P}:$ What progress is being made in Australia with regards to using art for health and wellbeing?

MM: It is interesting that the Journal for Applied Arts \& Health commenced life a decade ago, at the same time as our conference, which is a living journal and historical record of the field too. I have been privileged to know some of the best minds and hearts in the international field to usher in broad awareness of the benefits of arts and health in Australia. When I conceived the idea of a national organisation and an international conference around 2000, arts and health work was practiced in Australia under the banner of 'community cultural development'. Now there is strong recognition of the term 'arts and health' and what it represents, along with the special interest area of creative ageing.

We have a National Arts and Health Framework (2013), which was originally initiated through the Federal Government supporting our inaugural conference in 2009. Through the conference, we have showcased best practice international programmes, which could be replicated and adapted in Australia. As a result, there have been a number of international collaborations in practice and research, especially between Australia and the UK.

We are also seeing innovative work arising out of the special needs and circumstances in Australia such as the increasing rate of male suicide in regional locations and the mental health, family and social issues arising out of the 'Fly In, Fly Out' phenomenon around employment for mining projects in Western Australia and Queensland. The community needs of Aboriginal people have led to a diverse range of programmes including those by organisations such as DAADA, Beyond Empathy, bigHART.

NSW leads the way in fostering Dementia Friendly Communities across the state, under the auspices of a bipartisan parliamentary committee. 
The National Gallery of Australia (NGA) in Canberra launched their Art and Dementia mes in 2007 and following the inaugural conference in 2009, embarked on an outreach education programmes, commencing with a pilot programme at Port Macquarie regional gallery in 2010. Now, 32 galleries have participated in NGA training.

One area of focus in Australia relates to building the local research and evidence base to create a compelling socio-economic case to attract greater government, corporate and philanthropic support. Another area is the potential for training professional artists to work in health, community services and aged care. Playing the violin, guitar or harp does not necessarily equip a musician to bring solace and comfort to the bedside of a person at end of life. Trained artists have the knowledge to guide a young person who has experienced child abuse, enable a family to come to terms with chronic illness, or lead a Parkinson's dance class.

The rise of community choirs in Australia mirrors that trend in the UK, and increasingly choirs are led by trained musicians and singers, with an accent on physical and mental wellbeing. Arts and health in Australia has come a long way in ten years. This has partly been motivated by the rich traditions and expectations of our country's multi-culturally diverse communities.

\section{RP: I know that you have actively tried to dispel the misconception that art is an elitist} activity. How does this view translate into the community and how it engages with art?

MM: I was fortunate to attend a school where the arts were core curriculum, and not a 'nice to have' option. Creative activities now feature more strongly in education in Australia, with the recognition that the arts are essential for young people's mental, emotional and physical development.

All people are born creative. However, older people are often overlooked despite the fact that as people age, their creativity and imagination can be enhanced by physical changes though brain plasticity, increased recreational and leisure time and access to lifelong learning opportunities.

In the Australia of my youth, many people did not grow up with the arts and have subsequently formed the opinion that the arts are elitist. Older people are also mindful of the cost of admission prices and transport, especially after dark.

We need to remove the mental and physical barriers and encourage older people to participate in the arts by offering low cost or free admission to events, scheduled more often 
during the daytime, with access to safe and reliable assisted transport and 'cultural companions' who can share the enjoyment of cultural activities. Returned servicemen and sporting clubs (especially bowling clubs) in Australia play a valuable role in providing social activities which involve dancing, singing, theatre, comedy, bush poetry. Art gallery and museum societies, book clubs, libraries, theatre groups all offer ways for older people to participate with confidence in arts activities, while helping to dispel the elitist label.

One initiative that the NSW Ministerial Advisory Council on Ageing has implemented are annual Media Awards to recognise and encourage reporters, writers and photographers to represent older people in a positive light and profile successful intergenerational programmes. One example is the popular 'Ask Granny' progra in Australia, a tilt at the modern reliance on search engines.

$\boldsymbol{R P}:$ Where do you find your inspiration and who are the major influencers in your understanding of applied arts and health?

MM: The most pivotal person in fostering my commitment to the ideals of arts and health was the legendary Mike White, author of the book Arts Development in Community Health: a Social Tonic (2009).

I met Mike in Chicago at a SAH conference in 2006 and we became mates. He encouraged me in my quest to create an Australian arts and health organisation and an annual international conference and he presented at all of the conferences until his premature death in 2015. Mike was a wise and perceptive man with a cheeky sense of humour, deep intellect, enormous compassion and a big heart.

Mike was responsible for guiding the Angel of the North public art project in Newcastle Gateshead in the 90s. Sir Antony Gormley's sculpture led to massive social and economic infrastructure in the region, such as the Sage Arts Centre in Newcastle. The local council found that in some parts of the area, where there was significant disadvantage, the Angel had a direct impact on the health profile of the population, with improvements of up to $20 \%$.

This case study had a profound effect on the course my work has followed, including reinforcing my strong belief in the transformative power of public art. My long-time commitment to arts and health, and creative ageing, has certainly been inspired by knowing literally thousands of people who are doing incredible work, with many of them unsung heroes. I admire resources such as the excellent publications from the Baring Foundation (all 
accessible online) and your own Journal of Applied Arts \& Health. They are critical in distributing important information about the field in an accessible and demystifying way.

RP: There was an unusual project that you were once involved in called 'Hello Koalas'. What was this project all about?

MM: In 2011, Mike White and his arts and health colleague Mary Robson convened an international arts and health leadership forum at Durham University. There were 25 of us, including Elaine Burke, a professional artist and former arts and health manager with the NHS in England. Elaine had managed the cultural tourism sculpture project 'Larkin with Toads' in Hull in 2010 and it had proved immensely successful in social, artistic and economic terms. With a passion for public art and its ability to build community and social capital, I asked Elaine to help me establish a public art project in my local regional community of Port Macquarie, where I had recently relocated from Sydney. The result has been the Hello Koalas Sculpture Trail. Launched in 2014, with 50 sculptures, by this year's end, the Trail will encompass 70 one metre high koala fibreglass sculptures, featuring hand painted and applied designs, many with a strong environmental and arts and health theme. Locals and visitors are equally impressed by the highly talented artists represented on the Trail.

The best buzz I get is seeing three generations, out and about following the Trail, having fun and engaging in spirited conversation, often about koalas as a threatened species and the importance of protecting the environment. A healthy environment makes for a healthy and connected community and the arts offer a powerful medium to engage people on a number of levels and highlight important societal issues like wildlife conservation while also engaging people personally with the creative process. Now we are travelling our Hello Koalas sculptures to National Parks Visitor Centres, botanical gardens and zoos, spreading this cultural and environmental message and we have plans underway for our Hello Koalas to visit New York and hopefully the UK.

RP: So how would you summarize the actual benefits of the arts to health and wellbeing?

MM: Irrespective of age and culture, the arts excite the imagination in a unique way and enable people to feel good within themselves and the world around them. The arts enable 
people to socially engage with others in a non-intimidating way which reduces feelings of isolation, loneliness and anxiety. The arts are a lifetime companion.

$\boldsymbol{R P}:$ Reflecting on the last 10 years in particular, what might you have done differently in terms of arts, health and creative ageing agenda and why?

MM: That's a big question!

Trust and respect are critical factors in achieving sustainability and continuing innovation in the arts and health world. It is important to seek enduring partnerships with people with shared values and both personal and professional objectives. When I became involved in the arts and health field in the late 90s, it was virtually unrecognised in Australia although much of the community cultural development work taking place at that time was, in my view, arts and health.

I reviewed the progress of the arts and health field in the UK and the US from 80s and learnt about the challenges for member organisations to flourish and find reliable funding. We did not pursue that model and that was the right decision. I was fortunate to achieve strong support from key stakeholders who have shared my vision over the years. But in retrospect, I would probably have taken a less ambitious course.

Australia is a large country with a small population and 'making a difference through a new lens' can prove incredibly hard, especially given the time required to advocate for government policy and financial support. But I do believe that our conference and advocacy work has made a strong contribution to building the arts, health and creative ageing field in Australia and internationally and has contributed to moving arts and health practice into a mainstream endeavour with more widespread acceptance.

$\boldsymbol{R P}:$ Looking ahead, what do you see as the major challenges for the field, not only in the Australia but globally?

MM: The field has grown exponentially in recent years and with growth comes growing pains - accompanied by a changing of the guard as many people in the arts and health world are retiring and mentoring emerging leaders to take their place. I had hoped to establish a more formal international network for the arts and health field to provide guidelines for the future and enable members of the next generation to grow into leadership roles. Perhaps that will come. 
I believe education and training remain the key area of potential in arts and health globally. The newly formed National Organisation for Arts and Health (NOAH) in the US is working on an accreditation process for arts and health professionals, led by Helen Currier from Texas Children's Hospital and others, but there are so many challenges within countries, let alone finding a common ground internationally. That is why international meetings and associated networks are the lifeblood of the arts and health field.

RP: Out of everything you have achieved in your life, for what would you most want to be remembered?

MM: Positively impacting on people's lives through arts, health and creative ageing - on a large and small scale. Fostering a caring and loving family and being a steadfast and loyal friend.

RP: Thank you Margret, the Journal of Applied Arts and Health salutes you!

\section{References}

Standing Council on Health and Cultural Ministers (2013), National Arts and Health Framework, Perth: Meeting of Cultural Ministers Department of Culture and the Arts Government of Western Australia, http://mcm.arts. gov.au/national-arts-and-healthframework, accessed 1 May 2019.

White, M. (2009), Arts development in community health: A social tonic. Oxford: Radcliffe Publishing.

\section{Contributor details}

Professor Ross W. Prior is best known for his work in applied arts and health as founding principal editor of the Journal of Applied Arts and Health, established in 2009. In 2015 he was appointed the inaugural Professor of Learning and Teaching in the Arts in Higher Education at the University of Wolverhampton, United Kingdom. At the time of publication 
he is a member of the Arts \& Humanities Research Council (AHRC) Peer Review College. He is a Fellow of the Royal Society for Public Health and Principal Fellow of the Higher Education Academy. His latest book is Using Art as Research in Learning and Teaching (Intellect).

Contact:

University of Wolverhampton, Faculty of Arts, The Performance Hub, Walsall Campus, Gorway Road, Walsall WS1 3BD, United Kingdom.

E-mail: r.prior@wlv.ac.uk

ORCID: 0000-0002-1521-5552 